\title{
USING EDUCATIONAL DIGITAL TOOLBOX IN E-LEARNING TO BOOST STUDENTS' READING MOTIVATION IN COVID-19 PANDEMIC
}

\author{
Anastasia Dewi Anggraeni, Helda Jolanda Pentury \\ Department of English Education, Faculty of Language and Arts, Universitas Indraprasta PGRI \\ TB. Simatupang, Jl. Nangka Raya No.58 C, South Jakarta, Indonesia \\ Corresponding Author: anastasia.dewi@unindra.ac.id
}

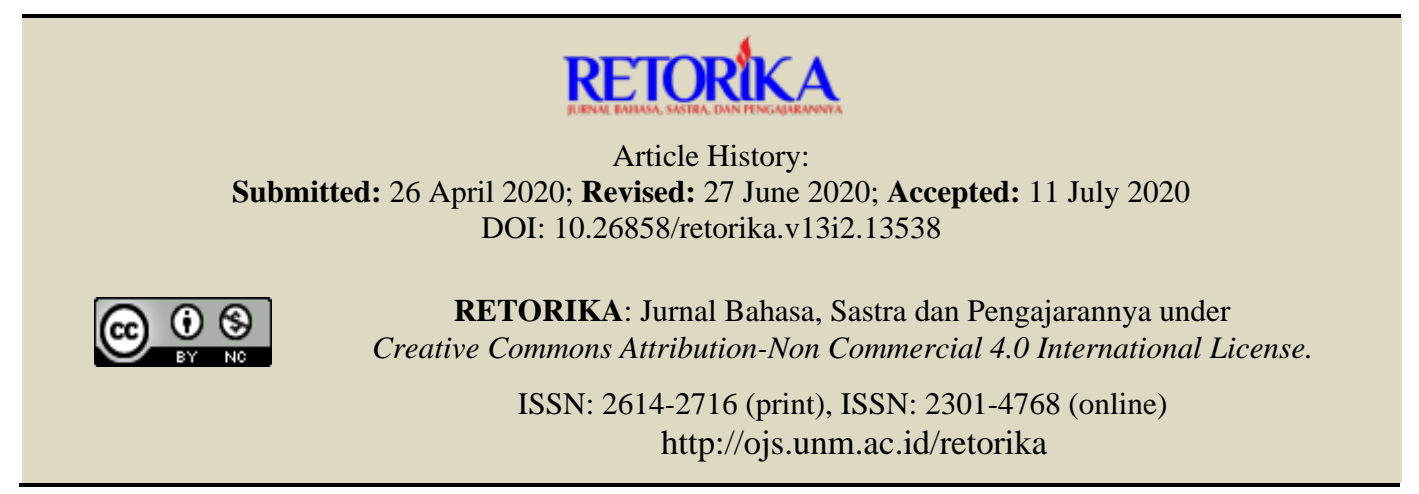

\begin{abstract}
This study aimed at investigating the use of educational digital toolbox in e-learning to motivate college students' reading motivation, such as recognizing ideas, comprehending texts using graphics, images, and charts, audio, audio-visual and video to personal experience, opinion or evaluation. The study attempted the qualitative method. The instrument used was a questionnaire which were prepared for the purpose and which was administered to 84 students at Indraprasta university, majoring in English education department in South Jakarta, during March and April 2020. The result of this study shows most of students boost their reading motivation by using educational digital toolbox in e-learning process. Give the new perspective that language students can be motivated to use long distance learning more active and more interactive, as well as enrich their learning experiences. Moreover, using appropriate pedagogical implementations such as effective digital toolboxes, interesting reading topics and students'feedback can boost students' reading motivation with the changing learning trend.
\end{abstract}

Keywords: digital toolbox, reading, e-learning, motivation

During these uncertain times of the COVID-19 pandemic, various companies around the globe, including those in Indonesia, have imposed a "work from home" (WFH) or "study from home" (SFH) policy for their employees, teachers, lectures and students. The WFH and SFH policies, which applied for an extended period of time and could last more than two weeks or more, will affect employees, teachers, lectures and students' working and learning habits very differently from a few remote working stints here and there. Teachers as professional initiate to provide online learning as an alternative to stay productive and maintain the learning process to still continue. This policy, to study from home might be more challenging for conventional professionals who were more used to a conservative and authoritarian learning style. The sudden shift from face-to-face to long-distance 
online learning forced teachers to use the technology (Putri et al., 2020).

Therefore, professionals of the 21 st century think and act differently than those of previous centuries, due at least in part to the radically different tools they use to perform their jobs. However, the concept of digital literacy goes well beyond the integration of technology. This type of technology knowledge entails the literacies, or practices, that are used to engage in meaningmaking productions through the use of digital tools (Peterson-ahmad \& Stepp, 2016). There has been much written about the diversity and range of practices that are associated with new technologies and the respective need for school literacy provision to be better aligned to those in everyday life (McDougall et al., 2018)

With the development of learning technologies in the late 20th century, education system has changed rapidly. This is due to the capability of technology to provide a proactive, easy access and comprehensive teaching and learning environment. Nowadays some of the institutions have provided their facilities and training in order to enhance the use of advanced technologies in teaching and learning process. A high budget has been placed in order to provide the equipment needed by them to improve the education system. Despite all the efforts, most of the countries are facing similar problem whereby the teachers are not maximizing the usage of the technology provided (Ghavifekr \& Rosdy, 2015). Unfortunately, our university, Indraprastra has not taken steps to implement technology-based education approach.

In accordance with the world trends in the development of education, and university, including today, the actual technology is elearning, based on the use of distance learning technologies in the form of electronic educational resources. E-learning is an implementation of electronic media for a variety of learning purposes to facilitate the delivery of distance education, online learning or blended learning. There are many terminologies regarding the elearning which includes distance education, blended learning, hybrid learning, online learning etc. J.J. Roberts (Kassymova, 2019) asserts that distance education implies a teaching and learning processes which take place separately from each other. It means that there is a geographical and physical separation between a teacher and a student in both place and time.
Learners acquire knowledge separated from their teachers whereas students interact with educational materials, classmates and teachers in a blended learning system through both an online learning environment.

The children of digital generations experience a world through computers, internet, and social online sites like a Facebook, Twitter, Google, iPhone's, iPad's. Usually, by interacting with other individuals humans learn, but today young pupils prefer to interact through social networking sites and around $30 \%$ of them have a blog in the web, and $62 \%$ have a profile on internet. Young people favor to expose them, to be active and collaborate using newest technology and visualization. Therefore, the way of teaching should be completely altered in order to meet those challenges and to response to the new requests (Dineva et al., 2019).

Based on the results of the Speak Up 2007 national survey (Ertmer \& Ottenbreit-Leftwich, 2010), $51 \%$ of the responding teachers $(\mathrm{n}=$ 13,027 / 25,544) reported that their primary uses of technology to "facilitate student learning" comprised (a) asking students to complete homework assignments using the computer (e.g., writing reports, finding information on the Internet) and (b) assigning practice work at the computer (e.g., using drill-and-practice software). These results are verified, to some extent, by the large percentage of students (grades 6-12) taking the same survey who reported using technology to (a) write assignments (74\%), (b) conduct online research (72\%), and (c) check assignments or grades online (58\%). In this study we considered the ways that teachers who conduct the teaching-learning process out of the box practice the use of digital toolbox as e-learning media to observe their students' motivation of the lessons, particularly in reading subject.

E-learning is a part of instructional design as Merrill et al. (Villesseche et al., 2019) defined it: "a technology for the development of learning experiences and environments which promote the acquisition of specific knowledge and skill by students". E-learning is an implementation of electronic media for a variety of learning purposes to facilitate the delivery of distance education, online learning or blended learning. There are many terminologies regarding the elearning which includes distance education, blended learning, hybrid learning, online learning etc. J.J.Roberts (Kassymova, 2019) asserts that 
distance education implies a teaching and learning processes which take place separately from each other. It means that there is a geographical and physical separation between a teacher and a student in both place and time. Learners acquire knowledge separated from their teachers whereas students interact with educational materials, classmates and teachers in a blended learning system through both an online learning environment.

The e-learning concept mean all the computer based educational tools or systems will allow the learners to get their education anytime and anywhere. In the past the e-learning used the CD-ROM, and the other blend of computer-based methods. Nowadays the Internet has become the main method for delivering e-learning (Hamad, 2017). E-learning satisfaction depends on wellplanned interaction mechanisms since interaction is important for both instructors and students. And in order to facilitate supportive and corrective feedback, instructors must design highly interactive settings (Hamutoğlu et al., 2019).

The use of digital toolbox in e-learning was applied by the students of English education department in university of Indraprasta to present the information through text, graphics, images, audio and video provides a complex multisensory experience. It may be awkward in the beginning, but teachers had to delivered their elearning assignments in time during this uncertainty condition and provide the qualified education using high-tech $21_{\text {st }}$ century teaching and learning set-ups.

In fact, the results of the study show that technology enhanced multimedia instruction allowed teachers to tailor instruction to diverse student needs and styles and provided opportunities to exercise student thinking skills. Besides, students are different in their abilities and their learning style varies from person to person. Responding to this argument, furthermore, Sambadandamurthi \& M.J, 2017 said that multimedia facilitated instruction may enhance student's attention capability and retention level as well. Hence multimedia packages and technology enhanced instructional strategy will facilitate students reading ability at all grades (Sambandamurthi \& M.J, 2017). To do this, teachers can use a variety instructional methods and media, as well as follow different pedagogical approaches aided by technology.
The global challenge faced by the teachers is to come up with a program that improves the quality of learning in line with technological advancement. Moreover, the results are in line with a research findings by Ghavifekr \& Rosdy (2015) that technology-based teaching and learning is more effective in compare to traditional classroom. This is because, using ICT tools and equipment will prepare an active learning environment that is more interesting and effective for both teachers and students. Therefore, the modern teaching and learning process is more adaptive to students' different paces and styles; teachers can explore diverse programs or software to adapt to the students' needs.

The digital educational resource for different topic includes a lot of special tasks for training (typical tasks) and cognitive (with elements of creativity) character. The aim of the training programs is to form appropriate skills and abilities for students. Moreover, examples of solving all typical tasks from the self-control unit are given in the content of the relevant lectures. The goal of cognitive programs is the formation of professional thinking (Gilmanshin \& Gilmanshina, 2018). In this model, the role of the students is simply to receive and store information taught in the class. Many students quickly tire of this teacher-centered model of reading learning; they complain that the lessons are boring, monotonous and that they want something new and different. It is, therefore, important to use a variety of teaching media and methods to make the e-learning stimulating and interactive in order to help students motivate in reading lesson.

Reading is a process of readers combining information from a text and their own background knowledge to build meaning" (Nadhif \& Wawan, 2019). Accordingly, a major goal of teaching reading comprehension is to help students develop the knowledge, skill, and experience they need to become independent readers and lifelong learners. Reading is one important skills in teaching learning, because it's will be gain their knowledge. Moreover, they can improve their vocabulary and also they can get more information what they need. Because so many books and resourches use English (Sopyan et al., 2019). A reading skill can be described as "a cognitive ability which a person is able to use when interacting with texts" (Liu, 2010). According to Grabe (Mustafa et al., 2019), there are five core reading comprehension skills which 
should be taught to help students comprehend texts, i.e., main idea, reading strategies, grammar, discourse, and vocabulary. However, the classification of reading comprehension skills by Gear and Gear (Mustafa et al., 2019) is more practical for teaching purposes, i.e., main idea, detail information, inference, reference, and vocabulary.

There are the following types of reading and the corresponding types of activities to develop the corresponding reading skills: (1) Skimming reading is reading to confirm expectations; reading for communicative tasks; (2) General reading or scanning is reading to extract specific information; reading for general understanding; (3) Close reading or searching reading is reading for complete understanding; reading for detailed comprehension (information; function and discourse) (Kozak, 2011). Skimming is the most rudimentary type of reading. Its object is to familiarize you as quickly as possible with the material to be read. Scanning is a skill that requires that you read quickly while looking for specific information. To scan a reading text, you should start at the top of the page and then move your eyes quickly toward the bottom. Generally, scanning is a technique that is helpful when you are looking for the answer to a known question. Close reading is the most important skill you need for any form of literary studies. It means paying especially close attention to what is printed on the page. Close reading means not only reading and understanding the meanings of the individual print- ed words, but also involves making yourself sensitive to all the nuances and connotations of language as it is used by skilled writers.

But aside from the importance of using digital toolbox in achieving language teaching success, skillful teachers know how to convey the lesson in an appropriate way and how to arouse their students' interest by means of using digital toolboxes. Therefore, a proper combination of multimedia and teaching methodology is appropriate to attract and maintain the students' attention during reading lessons. This study aims to identify the use of digital toolbox in e-learning on motivation in students' reading lesson and to review the students' ideas on how to use digital toolbox in e-learning effectively. Wainwright (Yulianto et al., 2020) suggests several factors that influence the quality of comprehension include: (1) reading speed, reading speed that does not pay attention to reading goals or is too fast in reading so that ignoring the overall reading content, can have detrimental effects on understanding, (2) reading goals, the purpose of reading is closely related to motivation in reading and interest in reading material. Setting clear goals can often create motivation and increase reading interest, thereby automatically increasing understanding, (3) the nature of the reading material, meaning that the material provided is interesting and the language is easy to understand. Reading material is an important component in reading because reading material is the main means, (4) the layout of reading material, namely organizing reading in describing a reading idea and a chart, picture, or graphic that serves to help the reader to more easily understand reading, (5) the environment in which reading, the environment in which to read is undoubtedly its influence on reading comprehension. An environment with a calm atmosphere will certainly make the reader more easily understand the reading than a crowded or noisy environment.

When you take time to read in or to your class, you are not neglecting the urriculum. Reading is the curriculum. The principal ingredient of all learning and teaching is language. Not only is it the tool with which we communicate the lesson, it is also the product the student hands back to uswhether it is the language of ath or science or history (Megyeri, 2015).

Also, reading improves writing skills for it enables the learners to figure out how to express ideas through words, how to use punctuation correctly, and so on. According to Elley (Pardede, 2019), there was a "spread of effect from reading competence to other language skills - writing, speaking and control over syntax".

Therefore, the researchers reviewed some studies suggesting new methods, strategies and techniques to try tackling the lack of students reading motivation to enable students to grasp the reading text effectively. Using digital toolbox is one of the most efficient ways to make the lessons audio-visual, to supply fluent and effective reading skills, to keep the students away from memorization, to obtain understanding and performance in perception. Using educational digital toolbox in e-learning and the environments they support can boost motivate the students to read, increase the students' control over the material being presented, and allow the students to take an active role in the e-learning process. 


\section{METHOD}

The study attempted the qualitative method by using observations in learning process, instruments, and documents (teaching material and their projects of reading using digital toolboxes). The instrument used was a questionnaire which were prepared for the purpose and which was administered to 84 students, (61 females and 23 males) at Indraprasta university, majoring in English education department in South Jakarta, during March and April 2020. The students were studying in the same reading course but were at two different classes. They were firstyear students in second term in 2020/2021. The questionnaires were composed of twenty questions about motivation of reading lesson and the use of digital toolbox in e-learning process. Questionnaires seem to be very popular among educational researchers in general and ELT researhers in particular. Another feature of qualitative research is that the data can be analysed using an open ended approach (Sharma, 2010). Generally, there are two types of questions in quesionnaires: closed-questions and open-ended questions. We prefer to choose open-ended questions that suggested by Foddy (Reja et al., 2003) that open-ended questions allow the respondents to say freely what is on their minds without being influenced by the researhers.

In such an open ended approach the data can be analysed with respect to the research questions and the theories posed by the researcher as well as theories of what is occurring that can come out of the data itself.

Cohen et al. (Sharma, 2010) call this a grounded theory approach where the analysis of the data comes from looking at the data. Grounded theory data analysis can be done by a constant comparative approach. A They are powerful evaluation tool widely used in empirical research because they propose a flexible means of collecting both qualitative and quantitative data.

Quesionnaire design is based on the types of information to be gathered and kinds of data to be measured. In the case of open-ended questions, Co-hen, Manion, and Marrison said that the coding frame was developed by examining a sample of responses and calculating a frequency tally, upon which the validity of the coding frame was checked further by coding a larger sample (Xerri, 2017). This method is in line with the recom-menddation to analyze open-ended questions "by describing the trends, themes or patterns of ideas you find in them"

The purpose of the current study is to examine the use of educational digital toolbox in e-learning to boost students' reading motivation. Multimedia approach is used to describe and analyze the students' reading motivation by using digital toolbox in e-learning process. Two classes were assigned as the participant of the study. The research includes two variables; the first variable is a digital toolbox. The second variable is students' reading motivation. Both classes were taught reading lessons via e-learning by using digital toolbox. The survey lasted for five weeks. To achieve the aims of the study, the researchers used questionnaires aimed at measuring the degree of importance of students' reading motivation for first-year college students 2020/2021 were prepared by Reading Syllabus as and digital toolbox in e-learning as questionnaires. Teachers designed and shared the link of the questionnaires to the students to fill via Google drive.

\section{FINDINGS AND DISCUSSION}

\section{Findings}

The respondents consisted of 23 male students and 61 female students. The results of the questionnaires that applying the use of toolbox in e-learning and student's motivation in reading are shown in the graphics and a table below. These data were also used to clarify and present with analysis and interpretation.

Based on the results of 84 respondents can be seen student responses to each question item: (1) Students as much as $41.7 \%$ agree with distance learning (e-learning) which is held at the moment in the midst of the pandemic Covid-19, which requires people to be social distancing.

Figure1. Student Response to e-Learning

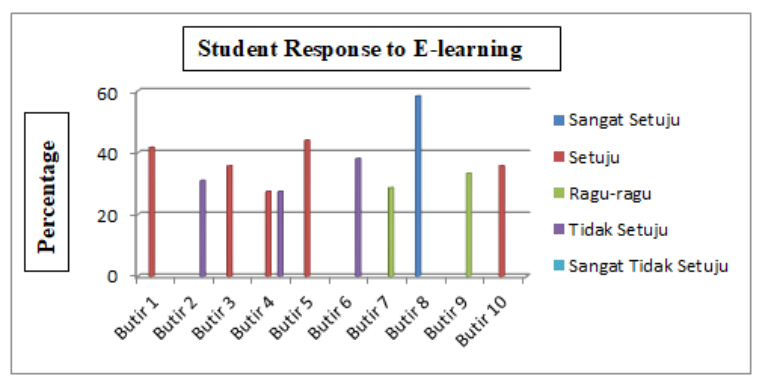


342 RETORIKA: Jurnal Bahasa, Sastra, dan Pengajarannya,

Vol. 13, No. 2, August 2020, pp. 337-345

Furthermore, number (2) As many as 31\% of students said they did not agree that distance learning (e-learning) made it easy for students to interact with lecturers; (3) Interaction with lecturers is more familiar expressed by students with a percentage of $35.7 \%$; (4) Expressing the problems faced in lectures to lecturers is more convenient through online using tools/technology rather than face to face. The statement was responded by $27.4 \%$ of students who agreed and $27.4 \%$ who disagreed; (5) Students feel comfortable to ans-wer the questions given in online lectures. The statement responded by $44 \%$ of students agreed; (6) Students prefer the learning environment to online lectures rather than face to face. The statement was responded by $38.1 \%$ of students disagree; (7) It makes no difference to my learning environment in online and face-to-face lectures. Because both are equally fun. The statement was responded by 28.6\% doubtful students; (8) Overall, distance learning makes lecturers give more assignments than face to face. The statement was responded to by $58.3 \%$ of students who agreed; (9) Distance learning makes students better understand the material. This statement was responded by $33.3 \%$ of students hesitated; (10) Students become more active and independent because of e-learning (distance learning). This statement was responded to by students as many as $35.7 \%$ agreed.

According to the findings, students believe that the use of digital toolbox (WAG, PPT, Google classroom, Zoom, Teams, etc.) in elearning motivate them to love reading. A large percentage $(82.9 \%)$ were of the opinion that digital toolbox in e-learning increase their motivation in reading lesson (question 1). Again a high percentage of the students (79.3) indicated that digital toolbox should be used in reading lesson (question 2).

Table1. The Results of Student Responses to Reading motivation

\begin{tabular}{ccccc}
\hline \multirow{2}{*}{$\begin{array}{c}\text { Questio } \\
\text { n Item }\end{array}$} & $\begin{array}{c}\text { Total } \\
\text { (person } \\
\text { ) }\end{array}$ & $\begin{array}{c}\text { Percentag } \\
\text { e (\%) }\end{array}$ & $\begin{array}{c}\text { Total } \\
\text { (person } \\
\text { ) }\end{array}$ & $\begin{array}{c}\text { Percentag } \\
\text { e (\%) }\end{array}$ \\
\hline 1 & 68 & 82,9 & 16 & 19,5 \\
\hline 2 & 65 & 79,3 & 17 & 20,7 \\
\hline 3 & 61 & 74,4 & 22 & 26,8 \\
\hline 4 & 65 & 79,3 & 19 & 23,2 \\
\hline 5 & 50 & 61 & 34 & 41,5 \\
\hline 6 & 58 & 70,7 & 25 & 30,5 \\
\hline 7 & 62 & 75,6 & 24 & 29,3 \\
\hline 8 & 47 & 57,3 & 37 & 45,1 \\
\hline 9 & 44 & 53,7 & 42 & 51,2 \\
\hline 10 & 34 & 41,5 & 49 & 59,8 \\
\hline
\end{tabular}

Figure 2. Student's Responses to Reading Motivation

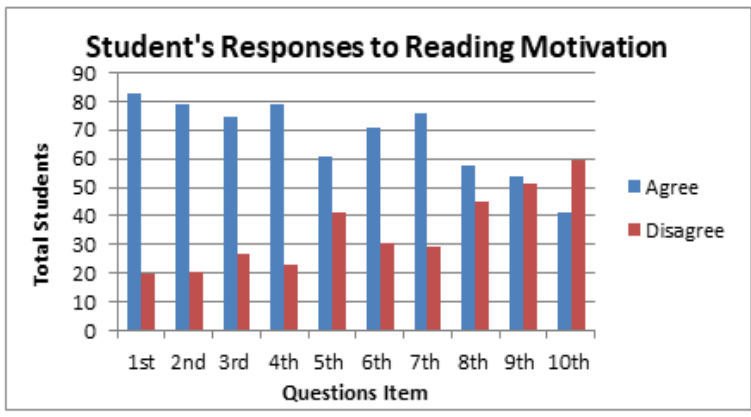

Answering question 3,74.4\% of the students believe that authentic materials downloaded from the internet and used by the teacher make the reading e-learning process more active. In question 4 most of the students $(79.3 \%)$ reported e-learning teaching activities make reading lesson more enjoyable. They agree that digital toolbox in e-learning never makes the lessons boring or unnecessary. The result of question 5 showed that $61 \%$ of the students agreed that digital toolbox should always be used in reading lesson to increase their motivation. They wanted to see different technological devices used as motivational tools. The $70.7 \%$ students agreed that the reading lesson seem more interesting and enjoyable when the teacher uses digital toolbox in elearning process (question 6). In addition, 75.6\% of the students agreed that tutorial using digital toolbox can be helpful to develop their reading skills in question 7. Looking at question 8, the students agreed that the fact of using digital toolbox every time e-learning process makes them interested in reading. Fifty-three point seven percent of the students reported in question 9 that they believe project work should be presented through digital toolbox in e-learning process. Surprisingly, the $59.8 \%$ of students' response disagreed in question 10 that e-learning-based lessons are more effective than traditional lessons.

\section{Discussion}

All through the process of observing and instructing learning reading strategies using digital toolboxes in e-learning, we have found that three main aspects related to the impact of using digital toolbox to boost students' reading motivation in e-learning. These aspects were; (1) students' reading motivation were reflected on 
reading using the toolboxes. During the learning process in e-learning taught, we noticed that the majority of the students enjoy using digital toolboxes in reading lessons and would like to continue to do so in the future. The interesting responses to the study though, are that the students clearly felt and motivated that there were some benefits to use the digital toolboxes in elearning reading lessons. The previous responded expreesed by Mutambik, 2018 that a significant component of this technology advancement is the development of the e-learning environment which has been recognised as having transformative potential in terms of English language teaching and learning methodology. Specifically, students can use E-learning resources to acquire the four main English language skills (listening, speaking, reading, and writing) (Mutambik, 2018).

Next, (2) the second aspect was the role of teacher to engage students into the use of digital toolboxes in reading e-learning process. Students today are already familiar with gadget and digital devices, and these give them the confidence to believe in their ability to accomplish learning tasks that involve its use. They enjoy making presentations in e-learning using creative apps such as Powtoon, Power Point and other presentation software and using videos downloaded from the internet. In our study, we found that the students were excited about having opportunity to test their skills and viewed the tasks as challenging and engaging. In line with the results of previous studies that the application of contemporary digital technologies allows attaining the following results in the education process: (1) Interactivity; (2) Quality of education; (3) Motivation; (4) Possibility of selfdependent work; (5) Improving of communicative competency; (6) Self-evaluation of the achieved level (Nedeva \& Dimova, 2010).

Then, (3) the third aspect was the importance of motivation when using digital toolboxes in reading e-learning process. Therefore, by changing teaching methods and incorporating the use of digital toolbox in e-learning such as creative Power Point presentations, tutorial videos, and audio files to present the lessons and its content, we believe students can be boosted their high motivation in reading or other lessons. This is in line with previous research which said that using tool opens doors to interact with the world. Reading creates the opportunity to learn and therefore learners should be offered the opportunity to improve their reading skills. Computer-assisted reading programs offer learners the opportunity that we as educationalists should embrace (Van Wyk \& Louw, 2008). Moreover, the researchers attribute this finding to involving students in technological environment such as in e-learning process which enables them to feel more relaxed, interactive, creative, and interested to use varied digital toolboxes to enrich their learning experiences.

During the implementation of the digital toolboxes in e-learning process, the role of the teachers were obstacles, as we had both students and teachers were unfamiliar with using digital toolboxes and e-learning, movig from simpler activities toward more complex activities during two weeks. It was tough for us to get familiar with the use of digital things.

The lack of devices, connectivity and learning experiences were the categories of the limitation. The geographical location of the living itself, the wi-fi access and learning experiences of using digital learning process showed in our study.

Finally, the affordances of the mobile devices owned by the learners were clarified in the study. Device considerations to use digital tool-boxes are also important for the learning and study design. Having the students using digital toolboxes in reading e-learning to boost their reading motivation were capable such as taking photos, or recording audio and video when reading using all creative toolboxes provided.

Despite the obstacles reffering to the use of digital devices and learning experiences above, the students had good motivation as the results of using digital toolboxes. They even could apply some apps in reading learning process by the end of the process they showed improvements in reading motivation by getting good reading performances. This suggests that if teachers make students aware of the learning process strategies and methods, the students would be more successful in reading learning process since they could boost their motivation, their learning tools to learn, and their academic potentials as well.

\section{CONCLUSION}

The students themselves acknowledge the relationship between motivation in reading lesson and the use of digital toolbox. The results of our 
studies lead us to make some varied perspectives that (1) educational digital toolboxes should be an integral part of the English language program, particularly in reading program; (2) language students can be encouraged to use long distance education as a way of making their learning more active and interactive; (3) The technological media or support available will determine different implementation strategies to motivate students in reading.

However, the fact that the students who did not agree with the question reflects the fact that digital toolbox in e-learning wasn't used well in the reading lesson and suggest that the way digital toolbox in e-learning should be reviewed. Besides, they agreed that they still need their real teacher not digital tutorial. Teachers should be made aware of the importance of using digital toolboxes contain creative authentic materials and variety of methods. A skillful creative teachinglearning process should be supported by the use of digital toolboxes in a way that supply students with added interest in the content and process of learning.

In our own experience of using digital toolbox such as Wordle apps, power point to present lectures to these students on reading lesson in research methods, we have found it to be a method that the students enjoy and which enables them to understand the content presented without difficulty. Using digital toolbox in e-learning makes the reading lesson interesting because they

\section{REFERENCES}

Bobek, E., \& Tversky, B. (2016). Creating Visual Explanations Improves Learning. Cognitive Research: Principles and Implications, 1(1): 114, doi.org/10.1186/s41235-016-0031-6

Dineva, S., Nedeva, V., \& Ducheva, Z. (2019). Digital Generation and Visualization in E-Learning Digital Generation and Visualization in ELearning. October.

Ertmer, P. A., \& Ottenbreit-Leftwich, A. T. (2010). Teacher Technology Change. Journal of Research on Technology in Education, 42(3): 255-284, doi.org/10.1080/15391523.2010.107 82551

Ghavifekr, S., \& Rosdy, W. A. W. (2015). Teaching and Learning with Technology: Effectiveness of ICT Integration in Schools. International Journal of Research in Education and Science, 1(2): 175, doi.org/10.21890/ijres.23596

Gilmanshin, I. R., \& Gilmanshina, S. I. (2018). find visual aids are helpful for learning. As an example, when studying research methods, students who do not know what is meant by 'research reading formatting' can gain a much better understanding through the use of tutorial videos which actually show them how to format a research reading paper and how to select the margin, etc. Creating visual explanations had greater benefits than those accruing from creating verbal ones. Surely some of the effectiveness of visual explanations is because they represent and communicate more directly than language (Bobek \& Tversky, 2016).

Digital toolbox in e-learning offers many benefits for the enhancement of students' reading motivation and this study has demonstrated that using it in the reading lesson as e-learning can be highly motivating for the students in this term April 2019 compare with their previous reading lessons before the pandemic situations. When elearning is employed, the students tend to attend the reading lesson regularly because the lessons look interesting and appealing. This is in mark contrast to the trend towards poor attendance which characterizes traditional reading classroom environment, where these are perceived to be boring and the students lack the necessary skills to achieve.

So, using digital toolboxes in e-learning can boost the students' reading motivation to actualize their academic potensial in reading lessons.

Technology of e-learning in the university education. IOP Conference Series: Materials Science and Engineering, 412(1), doi.org/10. 1088/1757-899X/412/1/012022

Hamad, M. M. (2017). Using WhatsApp to Enhance Students' Learning of English Language "Experience to Share." Higher Education Studies, 7(4): 74, doi.org/10.5539/hes.v7n4p74

Hamutoğlu, N. B., Savaşçı, M., \& Sezen-Gültekin, G. (2019). Digital Literacy Skills and Attitudes towards E-Learning. Journal of Education and Future, August, 93-107, doi.org/10.30786/jef. 509293

Kassymova, G. K. (2019). E-Learning and Its Benefits for Students. Modern Methods and Educational Technology, 4 (October): 249-255.

Kozak, M. (2011). The Types of Reading and Exercises for Teaching Reading. Unpublished, $7-10$. 
Liu, F. (2010). Reading Abilities and Strategies: A Short Introduction. International Education Studies, 3(3): 153-157. doi.org/10.5539/ies.v3 $\mathrm{n} 3 \mathrm{p} 153$

McDougall, J., Readman, M., \& Wilkinson, P. (2018). The uses of (digital) literacy. Learning, Media and Technology, 43(3): 263-279. doi.org/10. 1080/17439884.2018.1462206

Megyeri, K. A. (2015). Reading Aloud Student Writing. The English Journal, 85(3): 74-79.

Mustafa, F., Assiry, S. N., Bustari, A., \& Nuryasmin, R. A. (2019). The Role of Vocabulary eLearning: Comparing the Effect of Reading Skill Training With and Without Vocabulary Homework. Teaching English with Technology, 19(2): 21-43.

Mutambik, I. (2018). The Role of E-learning in Studying English as a Foreign Language in Saudi Arabia: Students' and Teachers' Perspectives. English Language Teaching, 11(5): 74, doi.org/10.5539/elt.v11n5p74

Nadhif, A., \& Wawan, H. (2019). Rider Strategy to Improve Students' Reading Skill. Jurnal Penelitian Islam, 13(02): 337-351, doi.org/10.1017 /CBO9781107415324.004

Nedeva, V., \& Dimova, E. (2010). Some Advantages of E-Learning in English Language Training. Trakia Journal of Sciences, 8(8): 21-28. http://www.uni-sz.bg

Pardede, P. (2019). Print vs Digital Reading Comprehension in EFL. Journal of English Teaching, 5(2): 77-90, doi.org/10.33541/jet. v5i2.1059

Peterson-ahmad, M. B., \& Stepp, J. B. (2016). Techniques Sam Houston State University College of Education Department of Language, Literacy and Special Populations. June.

Putri, R. S., Purwanto, A., Pramono, R., Asbari, M., Wijayanti, L. M., \& Hyun, C. C. (2020). Impact Of The Covid-19 Pandemic On Online Home Learning: An Explorative Study Of Primary Schools In Indonesia. International Journal of Advanced Science and Technology, 29(5): 4809-4818.

Reja, U., Manfreda, K. L., Hlebec, V., \& Vehovar, V.
(2003). Open-ended vs. Close-ended Questions in Web Questionnaires. Developments in Applied Statistics, 19(January): 159-177. http://www.websm.org/uploadi/editor/Reja_20 03_open_vs_close-ended_questions.pdf

Sambandamurthi, A., \& M.J, P. (2017). Technology Mediated Teaching for Students' Reading Skill in Technology Mediated Teaching for Students' Reading Skill in English. Research Journal of English Language and Literature (RJELAL), 4(2. 2016): 283-290.

Sharma, S. (2010). Qualitative Methods In Statistics Education Research: Methodological Problems And Possible Solutions. Proceedings of the Eigth International Conference on Teaching Statistics, 8. http://iase-web.org/documents/ papers/icots8/ICOTS8_8F3_SHARMA.pdf

Sopyan, F. M., Hasanah, K. U., \& Haryudin, A. (2019). Improving Reading Skill Using Jigsaw. PROJECT (Professional Journal of English Education), 2 (5): 745, doi.org/10.22460/ project.v2i5.p745-751

Van Wyk, G., \& Louw, A. (2008). Technologyassisted Reading for Improving Reading Skills for Young South African Learners. Proceedings of the International Conference on ELearning, ICEL, 2008-January (January 2008): 481-489.

Villesseche, J., Le Bohec, O., Quaireau, C., Nogues, J., Besnard, A. L., Oriez, S., De La Haye, F., Noel, Y., \& Lavandier, K. (2019). Enhancing Reading Skills Through Adaptive e-Learning. Interactive Technology and Smart Education, 16(1): 2-17, doi.org/10.1108/ITSE-07-20180047

Xerri, D. (2017). Using Questionnaires in Teacher Research. The Clearing House: A Journal of Educational Strategies, Issues and Ideas, 90(3): 65-69, doi.org/10.1080/00098655.2016. 1268033

Yulianto, B., Sodiq, S., \& Asteria, P. V. (2020). The Relevance of Standardization of Comprehension Reading Skills in 4.0 Era. 390 (Icracos 2019). doi.org/10.2991/icracos-19.2020.45 